\title{
Phylogenetic analyses reveal that Schellackia parasites (Apicomplexa) detected in American lizards are closely related to the genus Lankesterella: is the range of Schellackia restricted to the Old World?
}

Rodrigo Megía-Palma1, Javier Martínez², Dhanashree Paranjpe ${ }^{3,4}$, Verónica D’Amico ${ }^{5}$, Rocío Aguilar ${ }^{6,7}$, María Gabriela Palacios ${ }^{5}$, Robert Cooper ${ }^{3}$, Francisco Ferri-Yáñez ${ }^{8}$, Barry Sinervo ${ }^{3}$ and Santiago Merino ${ }^{1 *}$

\begin{abstract}
Background: Species of Schellackia Reichenow, 1919 have been described from the blood of reptiles distributed worldwide. Recently, Schellackia spp. detected in European and Asian lizards have been molecularly characterised. However, parasites detected in American lizard hosts remain uncharacterised. Thus, phylogenetic affinities between the Old and New World parasite species are unknown.

Methods: In the present study, we characterised morphologically and molecularly the hemococcidian parasites (sporozoites) that infect three lizard hosts from North America and two from South America.

Results: In total, we generated 12 new 18 S rRNA gene sequences of hemococcidian parasites infecting New World lizard hosts. By the microscopic examination of the smears we identified Schellackia golvani Rogier \& Landau, 1975 (ex Anolis carolinensis Voigt) and Schellackia occidentalis Bonorris \& Ball, 1955 (ex Uta stansburiana Baird \& Girard and Sceloporus occidentalis Baird \& Girard) in some samples, but the phylogenetic analysis indicated that all $18 \mathrm{~S}$ rDNA sequences are distant from Schellackia species found in Old World lizards. In fact, the hemococcidian parasites detected in the New World lizards (including S. occidentalis and S. golvani) were closely related to the genus Lankesterella Labbé, 1899. Consequently, we suggest these two species to be included within the genus Lankesterella.

Conclusions: Life history traits of hemococcidian parasites such as the type of host blood cells infected, host species or number of refractile bodies are not valid diagnostic characteristics to differentiate the parasites between the genera Schellackia and Lankesterella. Indeed, lankesterellid parasites with a different number of refractile bodies had a close phylogenetic origin. Based on the phylogenetic results we provide a systematic revision of the North American hemococcidians. Our recommendation is to include the species formerly described in the genus Schellackia that infect American lizards into Lankesterella (Lankesterellidae) as Lankesterella golvani (Rogier \& Landau, 1975) n. comb and L. occidentalis (Bonorris \& Ball, 1955) n. comb.
\end{abstract}

Keywords: Haemococcidia, Lankesterellidae, Lankesterella, Schellackiidae, Schellackia, Reptile

\footnotetext{
* Correspondence: santiagom@mncn.csic.es

'Departamento de Ecología Evolutiva, Museo Nacional de Ciencias

Naturales-CSIC, Madrid, Spain

Full list of author information is available at the end of the article
} 


\section{Background}

Lankesterella Labbé, 1899 [1] and Schellackia Reichenow, 1919 [2] are two genera of haemococcidian parasites of independent evolutionary origin that are nested within a paraphyletic Eimeriidae [3]. The evolutionary novelty in the life-cycle of parasites in these genera is the participation of a blood-sucking vector that exerts a mechanical role in the transmission between hosts. Therefore, the infective stages of the protozoans remain dormant in the transmitter without undergoing any development or modification [4]. Thus, at least in lizard hosts, transmission is accomplished by predation on the infected invertebrate (but see [5]). Some authors consider Lainsonia Landau, 1973 [6] as a third genus of hemococcidia that undergoes sporogony within reticuloendothelial host cells of the liver, spleen, lungs, kidney, and capillaries of the brain [4] in South American lizard host species [4, 7]. However, other authors prefer to consider Lainsonia as a synonym of Schellackia based on the common characteristic of their life-cycles, i.e. the presence of eight sporozoites in the oocyst $[4,8]$.

The genus Schellackia was originally described in European lizard hosts [2]. So far, species of Schellackia have been described infecting frog and lizard hosts from Europe, America, Asia and Africa [9-14]. Schellackia sp. was reported to infect the scincid lizard Egernia stokesii in Australia [15] but the identification of these parasites remains to be molecularly confirmed. The second hemococcidian genus, Lankesterella, was erected for a species infecting frogs [1]. Later, species of this genus were described infecting birds and lizards [3, 16-23]. The main morphological difference used to classify the hemococcidia into Lankesterella or Schellackia has been the characteristics of the oocyst during the endogenous development of the parasite. The presence of oocysts, normally in the lamina propia of the intestine, with eight naked sporozoites surrounded by a soft-walled oocyst, has been considered a diagnostic character for the genus Schellackia. In contrast, the presence of 32 or more sporozoites is the diagnostic characteristic for the genus Lankesterella [4]. However, the latter was true for Lankesterella spp. described in anuran hosts [8, 18, 21], since no endogenous development of Lankesterella spp. infecting lizard hosts has been described so far. The apicomplexan genera Lankesterella and Schellackia were largely believed to form a monophyletic clade within the family Lankesterellidae $[4,8]$. However, phylogenetic analyses revealed they have an independent evolutionary origin [3].

In lizards, there are 12 species of the genus Schellackia described worldwide [4]. Five of these were described from lizards in the Americas. Among these American species, three occur in Brazil (i.e. Lainsonia spp.) and two occur in North America (S. golvani Rogier \&
Landau, 1975 and S. occidentalis Bonorris \& Ball, 1955). The other seven parasite species, S. orientalis Telford, 1993 [24], S. calotesi Finkelman \& Paperna, 1998 [25], S. bolivari Reichenow, 1919 [2], S. brygooi Landau, 1973 [6], S. ptyodactyli Paperna \& Finkelman, 1996 [13], S. agamae Bristovetzky \& Paperna, 1990 [26] and S. bocagei Álvarez-Calvo, 1975 [27] were detected in Old World lizards [4]. The sporozoites show one refractile body (RB) in S. bolivari, S. bocagei, S. orientalis, S. brygooi, S. golvani and S. legeri (syn. Lainsonia legeri) [3, 4], whereas S. calotesi, S. ptyodactyli, S. agamae, S. occidentalis, S. landaue and S. iguanae (syn. Lainsonia iguanae) show a variable number of RB (between zero and two [4]). All these species were described infecting mainly erythrocytes, but also can infect lymphocytes and monocytes [4]. The exception is S. golvani that characteristically infects polymorphonuclear leukocytes [4, 10]. On the other hand, information on the Lankesterella parasites that infect reptiles is scarce. Only two species of Lankesterella, L. millani Álvarez-Calvo, 1975 [27] and L. baznosanui Chiriac \& Steopoe, 1977 [28], were described infecting lizard hosts in the world. However, according to Telford [4] these two taxa were not further considered as valid species because they were originally described based on insufficient morphological data.

No information on the molecular diversity and the phylogenetic affinities of the hemococcidia that infect New World lizard hosts is available. Therefore, we have sampled different populations of New World lizards belonging to the families Phrynosomatidae (genera Uta Baird \& Girard and Sceloporus Wiegmann), Iguanidae (genus Dipsosaurus Hallowell), and Liolaemidae (genera Liolaemus Wiegmann and Phymaturus Gravenhorst) to obtain molecular data that allowed the study of the evolutionary affinities between hemococcidia detected in Oldand New World host lizards. In addition, we present morphological data on the sporozoites found infecting the blood of the American lizard hosts studied here.

\section{Methods \\ Sampling methods}

We gathered several blood samples with hemococcidian parasites that were collected in different localities in North and South America. From California, blood was obtained from six infected Uta stansburiana hesperis Richardson (Phrynosomatidae) from Corn Springs (South California) and 12 from Los Baños (West California), 19 Sceloporus occidentalis bocourtii Boulenger (Phrynosomatidae) from Santa Cruz (West California), two S. occidentalis biseriatus Hallowell from high elevation (1800 masl) from the Sierra Nevada mountains (CA, USA) and one Dipsosaurus dorsalis Baird \& Girard (Iguanidae) from Boyd Canyon, Riverside County (South California). One infected sample of Liolaemus pictus Müller \& Hellmich 
(Liolaemidae) from Huinay (Chile) was also included in the study. All authors captured the reptiles using a noose tied to the end of a fishing pole (e.g. [3, 14]). All animals were processed and released on the same spot where they had been captured.

Blood samples were collected at the base of the tail using individual sterile needles (BD Microlance, Huesca, Spain). In the case of male lizards, the hemipenes bulges were always avoided to prevent harming the individuals. The area where the blood sample was obtained was previously cleaned with ethanol $96 \%$. Blood droplets were collected with the help of Na-heparinized microhematocrit tubes (BRAND, Wertheim, Germany). Blood samples were preserved in two different ways. First, thin blood smears were made for microscopic examination of infection. Blood smears were air-dried and fixed for $5 \mathrm{~min}$ in absolute methanol. All blood smears were stained with Giemsa stain $(1 / 10 v / v)$ for $40 \mathrm{~min}$. Slides were examined by the same operator for hemoparasites counting to 15,000 red blood cells (RBC) following Merino \& Potti [29]. We made microphotographs of the sporozoites observed under light microscopy and measured the length and the width of the sporozoites using the MBruler 5.0 free software (http://www.markus-bader.de/MBRuler/index.php) [3, 14]. Thereafter, we performed an ANOVA analysis to compare the size of the sporozoites that we detected in the two known hosts for Schellackia occidentalis: Sceloporus occidentalis and U. stansburiana. Secondly, the remaining blood (less than $20 \mu \mathrm{l}$ ) was preserved on Whatman FTA Classic Cards (GE Healthcare UK Limited, Buckinghamshire, UK). These cards allowed us to perform DNA extraction later [3, 14, 23].

D'Amico \& Aguilar [30] reported the presence of hemococcidian parasites in the blood of Phymaturus payuniae Cei \& Castro (Liolaemidae) from the cold desert in Patagonia, Argentina. These authors provided a tissue sample (tail tip) of one infected individual preserved in $70 \%$ ethanol for this study. Tail tissue samples allow the proper extraction of the apicomplexan DNA from the host tissue [31]. Similarly, we microscopically analysed the blood smear corresponding to the infected polychrotid lizard, Anolis carolinensis, reported in a previous study [23]. The infected lizard was one individual recently imported from Florida [23] that presented an intensity of infection of 21/15,000 RBC. In the present study, we compared the morphology of parasites found in the American lizards of genera Anolis [23], Sceloporus, Uta, Dipsosaurus, Phymaturus [30] and Liolaemus with previous species described infecting American lizard hosts using the morphological data available in Telford [4].

\section{Molecular methods}

We extracted genomic DNA from the blood preserved on FTA cards following the protocol described by
Megía-Palma et al. [14]. The DNA was then purified using the NZYGelpure kit (NZYTech, Lda., Lisbon, Portugal). Partial amplification of the $18 \mathrm{~S}$ ribosomal RNA gene sequence was performed using the primer set BT-F1/hep1600R or BT-F1/EimIsoR1 or BT-F1/EimIsoR3 (Table 1). These primers were previously used to amplify other coccidian species [3, 23]. PCR reactions (total volume of $20 \mu \mathrm{l}$ ) contained between 20 and $100 \mathrm{ng}$ of the DNA template. Supreme NZYTaq $2 \times$ Green Master Mix (NZYTech, Lda.) and $250 \mathrm{nM}$ of each primer were used. Using a Veriti thermal cycler (Applied Biosystems, Foster City, CA, USA), reactions were run using the following conditions: $95{ }^{\circ} \mathrm{C}$ for $10 \mathrm{~min}$ (polymerase activation), 40 cycles at $95{ }^{\circ} \mathrm{C}$ for $30 \mathrm{~s}$, annealing temperature at $58^{\circ} \mathrm{C}$ for $30 \mathrm{~s}, 72{ }^{\circ} \mathrm{C}$ for $120 \mathrm{~s}$, and a final extension at $72{ }^{\circ} \mathrm{C}$ for $10 \mathrm{~min}$. All amplicons were recovered from agarose gels and subjected to direct sequencing using an ABI $3730 \mathrm{XL}$ automated sequencer (Applied Biosystems). Amplicons whose chromatograms yielded double peaks were cloned using NZY-A Speedy PCR cloning kit (NZYTech, Lda.). Plasmids were purified using NZYMiniprep kit (NZYTech, Lda.).

Due to the weak signal obtained by PCR in some samples, we could only sequence 22 of the 41 amplicons that we obtained. The twelve different DNA sequences (18S rRNA gene) obtained in the present study were aligned together with other 98 sequences obtained from GenBank. The alignment was performed using PROBCONS (http:// toolkit.tuebingen.mpg.de/probcons). Poorly aligned positions and divergent regions of the alignment were suppressed using the GBlocks program [32] selecting the following options: minimum number of sequences for a conserved position $=56$; minimum number of sequences for a flank position $=56$; maximum number of contiguous nonconserved positions $=10$; minimum length of a block $=5$; and allowed gap positions $=$ with half. The final alignment contained 1441 positions and 110 sequences. The substitution model GTR + I + G was selected using jModeltest 2.1.4 [33] to perform the Bayesian analysis with MrBayes 3.2.6 software [34-36]. This analysis consisted of 2 runs of 4 chains each with 2,000,000 generations per run and a sampling interval every 100 generations. After a 'burn-in' of 500,000 generations was applied and 30,000

\begin{tabular}{|c|c|c|}
\hline Primer & Sequence $5^{\prime}-3^{\prime}$ & Amplicon size (bp) \\
\hline BT-F1 & GGTTGATCCTGCCAGTAGT & 1626 \\
\hline Hep1600R & AAAGGGCAGGGACGTAATCGG & \\
\hline BT-F1 & As above & 1580 \\
\hline EimlsoR1 & AGGCATTCCTCGTTGAAGATT & \\
\hline BT-F1 & As above & 1528 \\
\hline EimlsoR3 & GCATACTCACAAGATTACCTAG & \\
\hline
\end{tabular}


trees were obtained for consensus tree. The final standard deviation of the split frequencies was lower than 0.01. In addition, the alignment was also analysed using a maximum likelihood inference (PhyML 3.0 software) [37], using the substitution model listed above. The subtree pruning and regrafting (SPR) tree rearrangement option were selected, and a Bayesian-like transformation of aLRT (aBayes) was used to obtain the clade support [38]. Both trees were rooted with the family Sarcocystidae because this taxon is well established as a distinct but closely related family to the Eimeriidae $[8,14]$.

\section{ZooBank registration}

To comply with the regulations set out in article 8.5 of the amended 2012 version of the International Code of Zoological Nomenclature (ICZN) [39], details of the article have been submitted to ZooBank. The Life Science Identifier (LSID) of the article is urn:Isid:zoobank.org:pub:44981DFE-E5A2-446C-8865-DC90B73C90CD.

\section{Results \\ Morphological identification}

In total, 99\% (207/209) of the observed sporozoites had light blue refractile bodies (RB) (Fig. 1). The presence of $\mathrm{RB}$ is a morphological characteristic compatible with the morphology of the sporozoites in the hemococcidian genera Lankesterella and Schellackia [3, 4]. The number of $\mathrm{RB}$ in each of the parasite haplotypes is shown in Table 2. We observed 5\% (11/209) of the sporozoites free in the plasma, whereas the remaining 95\% (198/ 209) of the sporozoites were found infecting the cytoplasm of host blood cells. More, specifically $65 \%$ of the sporozoites infected red blood cells, and 30\% leukocytes. Host blood cells for the sporozoites of each parasite haplotypes are indicated in Table 2 .

The hemococcidian parasite found in the blood of Anolis carolinensis was morphologically identified as Schellackia golvani. The mean size of the sporozoites was $8.4 \times 3.9 \mu \mathrm{m}$ and all of them were observed in the cytoplasm of polymorphonuclear leukocytes (21/21) with a single $\mathrm{RB}$.

Sporozoites of Schellackia occidentalis were detected in the cytoplasm of erythrocytes and leukocytes of the lizard host Sceloporus occidentalis, and only in the cytoplasm of erythrocytes of the lizard host Uta stansburiana. In addition, in both host species we found few sporozoites that were free in plasma. In S. occidentalis, $51.8 \%(57 / 110)$ of sporozoites were observed in the cytoplasm of leukocytes (mean size \pm standard deviation, SD: $9.3 \pm 1.6 \mu \mathrm{m} \times 4.2 \pm 1.2 \mu \mathrm{m})$ (Fig. 1a); 42.7\% (47/110) were observed in the cytoplasm of erythrocytes (mean size \pm SD: $7.3 \pm 1.2 \mu \mathrm{m} \times 3.5 \pm 0.9 \mu \mathrm{m}$ ) (Fig. $1 \mathrm{~b})$, and $5.5 \%(6 / 110)$ were free in plasma (mean size \pm SD: $8.6 \pm 1.6 \mu \mathrm{m} \times 2.9 \pm 0.5 \mu \mathrm{m})$. In addition, $2 \%(2 / 110)$ of the sporozoites presented $0 \mathrm{RB}, 29 \%(32 / 110)$ presented a single one $\mathrm{RB}$, and $69 \%(76 / 110)$ presented $2 \mathrm{RB}$. In $U$. stansburiana hosts, $81 \%(21 / 26)$ of the sporozoites infected erythrocytes (mean size \pm SD: $9.2 \pm 1.3 \mu \mathrm{m} \times$ $3.2 \pm 0.7 \mu \mathrm{m})$ (Fig. 1e) and 9\% (5/26) were free in plasma (mean size \pm SD: $10.7 \pm 1.0 \mu \mathrm{m} \times 2.4 \pm 0.6 \mu \mathrm{m}$ ) (Fig. 1i) No sporozoite was observed infecting leukocytes. Besides, $73 \%(19 / 26)$ of the sporozoites presented $1 \mathrm{RB}$, and $27 \%(7 / 26)$ presented $2 \mathrm{RB}$. The sporozoites found in $U$. stansburiana were longer $\left(F_{(1,134)}=8.1, P=0.005\right)$ and narrower $\left(F_{(1,134)}=12.2, P=0.0006\right)$ than the sporozoites found in $S$. occidentalis. This result was independent of the type of cell infected (interaction: host species*type of cell infected: (length) $F_{(1,131)}=0.1$, $P=0.73$; (width) $F_{(1,131)}=0.02, P=0.88$ ).

\section{Molecular results}

We performed DNA extraction from the 41 samples where we found hemococcidians infecting blood cells in blood smears. We only sequenced 22 of the 41 (53\%) amplicons obtained. In total, we found 12 new haplotypes of hemococcidian parasites infecting New World lizard hosts (Table 3). The new sequence data are available in the GenBank database under the accession numbers MF167544-MF167555 (see also Additional file 1: Table S1). In North American hosts, we found six new haplotypes of the 18S rRNA gene of hemococcidian parasites infecting Phrynosomatidae and four infecting Iguanidae whereas, in South American hosts, we found two haplotypes infecting Liolaemidae lizards. The prevalence of each parasite haplotype in the host species sample is shown in Table 2 .

Bayesian inference and maximum likelihood phylogenetic analyses produced trees with an almost identical topology. All new haplotypes grouped together with Lankesterella parasites (Fig. 2). Ten of the 12 new haplotypes, including parasite sequences detected in $U$. stansburiana and Sceloporus occidentalis, were included with high phylogenetic support $(\geq 95 \%)$ in the same clade with sequences of Lankesterella parasites (i.e. Lankesterella sp. Ae-Lk and Lankesterella sp. Lank_anocar) detected in the North American host species, Anolis carolinensis, and in the Mediterranean host species, Acanthodactylus erythrurus (clade A). The group (named clade B) formed by L. valsainensis (detected in Eurasian avian hosts) and the type-species of the genus Lankesterella, L. minima (detected in Eurasian amphibian hosts), was a sister group to clade A (support $<80 \%$, Fig. 2). In addition, clade $C$ that grouped cloned haplotypes DD1 and DD4 detected in the desert iguana, $D$. dorsalis, from California, formed a third monophyletic clade within the family Lankesterellidae. This last clade was the sister group to the clade formed by the groups $\mathrm{A}$ and $\mathrm{B}$ with a statistical support of 0.78 by Bayesian 


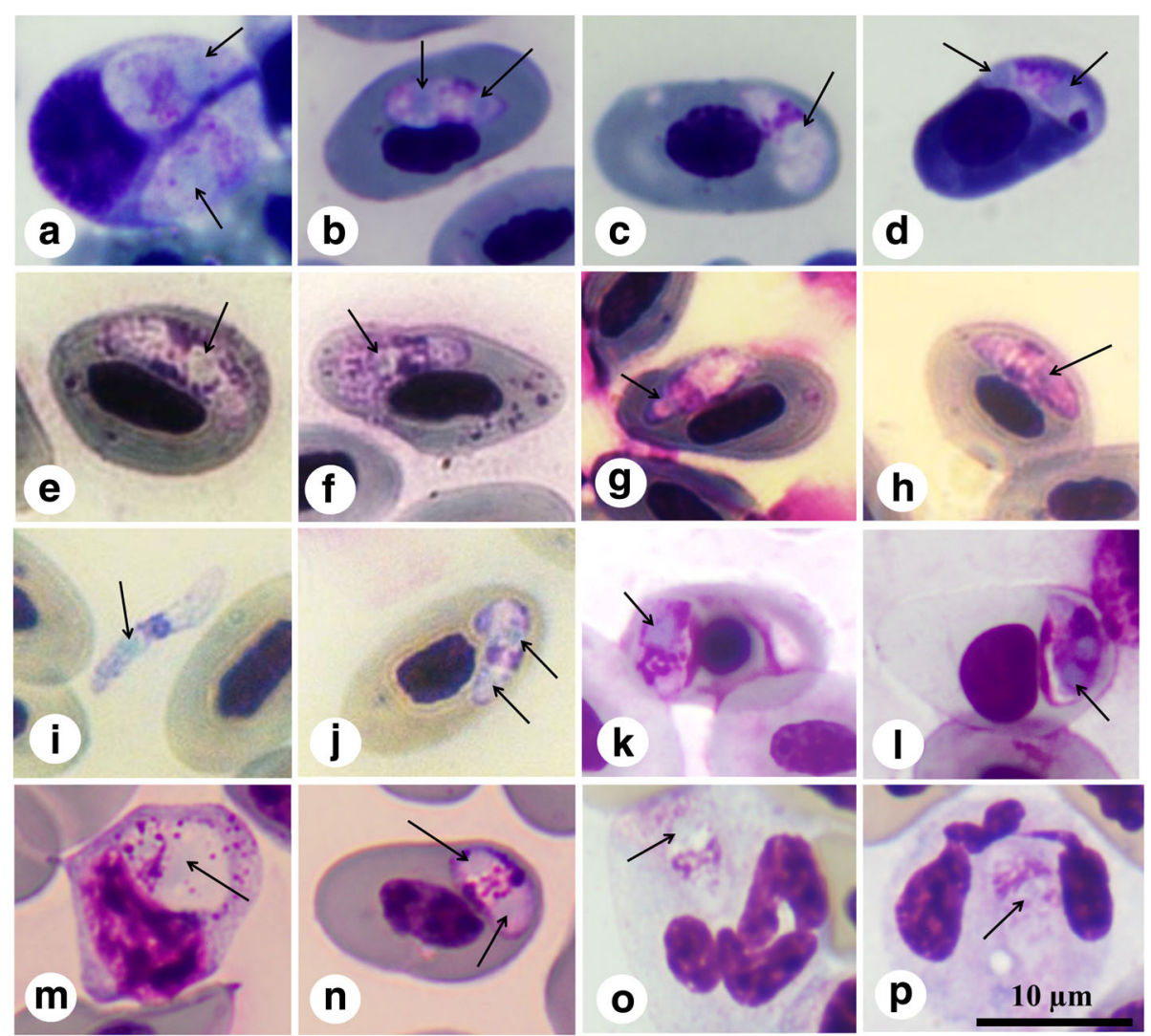

Fig. 1 Microphotographs of hemococcidian parasites infecting the blood of New World lizard hosts. Every pair of microphotographs corresponds to one specific haplotype as follows: $\mathbf{a}, \mathbf{b}$ and $\mathbf{c}, \mathbf{d}$ : SO1 and SO2 in Sceloporus occidentalis, respectively; $\mathbf{e}, \mathbf{f} ; \mathbf{g}, \mathbf{h} ;$ and $\mathbf{i}, \mathbf{j}$ : US1, US3 and US4 in U. stansburiana, respectively; i free sporozoite in the blood of U. stansburiana; $\mathbf{k}$, I: LP1 in L. pictus; $\mathbf{m}, \mathbf{n}$ : DD in one lymphocyte (m) and one erythrocyte (n) of $D$. dorsalis; $\mathbf{o}, \mathbf{p}$ Lankesterella sp. Lank_anocar in polymorphonuclear leukocytes of A. carolinensis. Arrows indicate RB in the sporozoites. All pictures were made at the same scale. Scale-bar: $10 \mu \mathrm{m}$

inference and $95 \%$ by maximum likelihood (Fig. 2). Additionally, clade D contained all previously known sequences of Schellackia parasites that were molecularly characterised from blood samples of Asian and European lizard hosts in previous studies [3, 14].

\section{Discussion}

Three Schellackia species are known to infect American lizard hosts: S. landaue, S. occidentalis, and S. golvani [4]. We detected parasites that are biologically and morphologically compatible with $S$. occidentalis and $S$. golvani. On the one hand, the sporozoites observed infecting the blood cells of Anolis carolinensis are morphologically (i.e. mean length and width [4]) compatible with the original description of S. golvani. Besides, the sporozoites were found infecting exclusively polymorphonuclear leukocytes, which is a unique characteristic of S. golvani $[4,10]$. On the other hand, parasites found in the blood samples of the lizard hosts Sceloporus occidentalis and Uta stansburiana are likely the same parasite formerly described as Schellackia occidentalis.
The size (i.e. mean length and width) of the sporozoites found infecting the blood cells of Sceloporus occidentalis was compatible with that originally described for the sporozoites of Schellackia occidentalis (Table 4) although the number of $\mathrm{RB}$ was not always consistent with the original description. However, previous experimental studies demonstrated that RB are dynamic structures within the Eimeriorina that can shift in size and number during the development of the sporozoite and fluctuate in number even in the sporozoites infecting an individual host $[4,40,41]$.

Considering that we included sequences of S. golvani and $S$. occidentalis in the phylogenetic analyses, it was unexpected that none of them were closely related to the family Schellackiidae (clade D) [23]. To our knowledge, this phylogenetic study is the first to compare hemococcidian parasites from American, European and Asian lizard species. We found strong phylogenetic support to conclude that the hemococcidian haplotypes detected in American lizard hosts are closely related to the genus Lankesterella and distant to the genus Schellackia. 
Table 2 Prevalence of each of the parasites haplotypes in the infected individuals of each host species, host cell type and number of RB for each of the described species of hemococcidia and parasite haplotypes that infect American lizards

\begin{tabular}{|c|c|c|c|c|}
\hline Parasite haplotype or described species & Prevalence (\%) (infected/examined) & Host species & Infected cell & $\mathrm{RB}$ \\
\hline SO1 & $79(11 / 14)$ & Sceloporus occidentalis & $E \& L$ & $1-2$ \\
\hline $\mathrm{SO} 2$ & $21(3 / 14)$ & S. occidentalis & $E \& L$ & $0-1$ \\
\hline US1 & $66(4 / 6)$ & Uta stansburiana & E & 1 \\
\hline US2a, US2 $b^{a}$ & $17(1 / 6)$ & U. stansburiana & E & 1 \\
\hline US3 & $17(1 / 6)$ & U. stansburiana & E & $1-2$ \\
\hline Schellackia occidentalis ${ }^{\mathrm{b}}$ & - & S. occidentalis and U. stansburiana & E (primarily) & $1-2$ \\
\hline Lankesterella sp. Lank_anocar & - & Anolis carolinensis & PL & 1 \\
\hline Schellackia golvani ${ }^{\mathrm{b}}$ & - & A. carolinensis & $P L$ & 1 \\
\hline $\mathrm{DD} 1, \mathrm{DD} 2, \mathrm{DD} 3, \mathrm{DD} 4^{\mathrm{a}}$ & $100(1 / 1)$ & Dipsosaurus dorsalis & E & $1-2$ \\
\hline LP1 & $100(1 / 1)$ & Liolaemus pictus & E & 1 \\
\hline $\mathrm{PP} 1^{\mathrm{c}}$ & $100(1 / 1)$ & Phymaturus payuniae & E & $1-2$ \\
\hline Schellackia landaue & - & Polychrus spp. & $E \& L(M, L y)$ & $1-2$ \\
\hline Lainsonia iguanae $^{\mathrm{b}}$ & - & Iguana iguana & $E \& L(M)$ & 2 \\
\hline Lainsonia legeri $^{\mathrm{b}}$ & - & Tupinambis nigropunctatus & L (M, Ly) & 1 \\
\hline
\end{tabular}

Abbreviations: $E$ erythrocyte, $L$ leukocyte, $M$ monocytes, $L y$ lymphocytes, $P L$ polymorphonuclear leukocytes, $R B$ number of refractile bodies

${ }^{a}$ Clone haplotypes US2a and US2b and clone haplotypes DD1, DD2, DD3 and DD4 were detected in a single U. stansburiana and a single D. dorsalis, respectively

${ }^{\mathrm{b}}$ Morphological data from Schellackia species obtained from Telford [4]

'Data obtained from D'Amico \& Aguilar [30]

Indeed, lankesterellids detected in North and South American lizards were more closely related to Lankesterella sp. Ae-Lk1 and Lankesterella sp. Lank_anocar, previously detected in Old and New World lizards [3, 23] (clade A) than to Lankesterella spp. detected in European bird and amphibian hosts (clade B). The phylogenetic affinity of clade $\mathrm{C}$ with the remaining clades within the Lankesterellidae showed medium to high phylogenetic support and, hence, it provides molecular evidence for a monophyletic origin of the genus Lankesterella.

Based on the phylogenetic affinities achieved here and the phylogenetic support for the monophyletic origin of the genus Lankesterella, our recommendation is to reclassify Schellackia golvani as Lankesterella golvani (Rogier \& Landau, 1975) n. comb., and S. occidentalis as L. occidentalis (Bonorris \& Ball, 1955) n. comb. Lankesterella occidentalis n. comb. seems to be composed of a diverse complex of haplotypes from parasites that infect different host species in North America (see [4]). Indeed, we characterised six different 18S RNA haplotypes in only two different host species of the family Phrynosomatidae. However, the specificity at the host genus level of American lankesterellids was high because none of the parasite haplotypes detected in Uta stansburiana was found in Sceloporus occidentalis (and vice versa) despite sampling ranges of the hosts and parasites overlapped (e.g. in California). This result suggests that $L$. occidentalis $n$. comb. may be a complex group of cryptic species similar to previous cases of parasitic species complexes [42]. Indeed, the significantly longer and narrower sporozoites of L. occidentalis n. comb. that infect $U$. stansburiana, in comparison to the sporozoites that infect S. occidentalis hosts, suggest that Schellackia

Table 3 Lizard host species and localities where each parasite haplotype was found

\begin{tabular}{llll}
\hline Parasite haplotype & Clade & Host species & Locality \\
\hline SO1, SO2 & A & Sceloporus occidentalis biseriatus \\
Sceloporus occidentalis bocourtii & Sierra Nevada and Santa Cruz, CA, USA \\
US1 & A & Uta stansburiana & Corn Springs and Los Baños, CA, USA \\
US2a, US2b & A & Uta stansburiana & Corn Springs, CA, USA \\
US3 & A & Uta stansburiana & Los Baños, CA, USA \\
DD1, DD4 & C & Dipsosaurus dorsalis & Boyd Deep Canyon, CA, USA \\
DD2, DD3 & A & Dipsosaurus dorsalis & Boyd Deep Canyon, CA, USA \\
LP1 & A & Liolaemus pictus & Huinay, Chile \\
PP1 & A & Phymaturus payuniae & Patagonia, Argentina \\
\hline
\end{tabular}




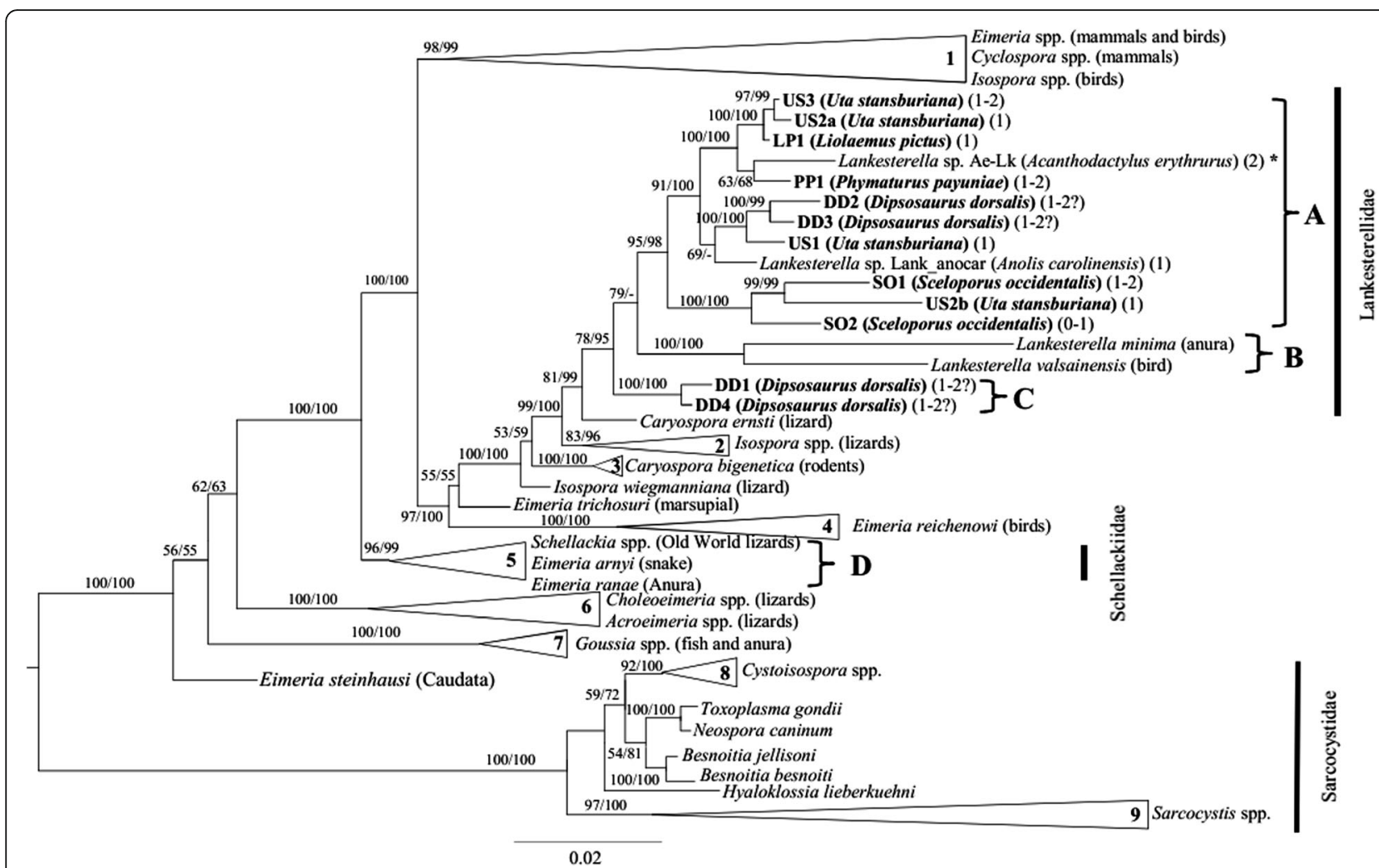

Fig. 2 Phylogenetic tree derived from Bayesian inference (BI) and Maximum Likelihood (ML) analyses. Node support provided as BI/ML; a hyphen indicates no phylogenetic support. Hosts from which the sequences were obtained are listed in parentheses. The number of refractile bodies in sporozoites is shown in parentheses after host name; a question mark in parentheses (haplotypes DD1 to DD4) indicates uncertainty in number of refractile bodies due to sequences originating from clonal amplicons detected in a single individual host. GenBank accession numbers of the sequences forming the collapsed clades are given in Additional file 1: Table S1. The scale-bar indicates the number of substitutions per site

Table 4 Morphometric data (in micrometres) for sporozoites of known hemococcidian species that infect American lizards and the new haplotypes found in the present study

\begin{tabular}{|c|c|c|c|c|c|c|}
\hline \multirow[t]{2}{*}{ Parasite haplotype or described species } & \multirow[t]{2}{*}{ Host species } & \multirow[t]{2}{*}{$n$} & \multicolumn{2}{|l|}{ Length } & \multicolumn{2}{|l|}{ Width } \\
\hline & & & Mean \pm SD & Range & Mean \pm SD & Range \\
\hline SO1 & S. occidentalis & 96 & $8.6 \pm 1.7$ & $5.1-13.5$ & $4.0 \pm 1.1$ & $2.1-10.3$ \\
\hline $\mathrm{SO} 2$ & S. occidentalis & 14 & $7.2 \pm 0.9$ & $5.7-8.6$ & $3.1 \pm 0.6$ & $2.1-3.8$ \\
\hline US1 & U. stansburiana & 2 & 10.1 & $10.0-10.2$ & $3.3 \pm 0.6$ & $2.9-3.7$ \\
\hline US2a, US2b & U. stansburiana & 12 & $9.3 \pm 0.6$ & $8.5-11.0$ & $3.4 \pm 0.8$ & $2.1-5.3$ \\
\hline US3 & U. stansburiana & 12 & $9.5 \pm 1.9$ & $5.4-12.0$ & $2.6 \pm 0.5$ & $1.6-3.7$ \\
\hline Schellackia occidentalis ${ }^{a}$ & S. occidentalis and U. stansburiana & - & 7.8 & $5.6-9.6$ & 3.6 & $2.8-5.6$ \\
\hline Lankesterella sp. Lank_anocar & A. carolinensis & 21 & 8.4 & $7.1-9.9$ & 3.9 & $2.6-4.5$ \\
\hline Schellackia golvania & Anolis spp. & - & 8.2 & $7.6-10.7$ & 3.3 & $3.1-3.8$ \\
\hline DD1, DD2, DD3, DD4 & D. dorsalis & 63 & $7.9 \pm 1.3$ & $5.2-11.3$ & $3.7 \pm 0.8$ & $2.2-6.1$ \\
\hline LP1 & L. pictus & 4 & $6.5 \pm 0.6$ & $5.9-7.4$ & $3.5 \pm 0.7$ & $2.7-4.1$ \\
\hline$P P 1^{b}$ & P. payuniae & 7 & $8.8 \pm 1.9$ & $7.1-12.7$ & $4.3 \pm 0.7$ & $3.1-5.2$ \\
\hline Schellackia landaue ${ }^{a}$ & Polychrus spp. & - & 13.0 & - & 3.0 & - \\
\hline Lainsonia iguanae $^{a}$ & Iguana iguana & - & 11.0 & - & 7.0 & - \\
\hline Lainsonia legeri ${ }^{a}$ & Tupinambis nigropunctatus & - & 9.5 & - & 4.0 & - \\
\hline
\end{tabular}

Abbreviation: $S D$ standard deviation

${ }^{\mathrm{a}}$ Data of Schellackia species from [4]

${ }^{\mathrm{b}}$ Data from [30] 
occidentalis was formerly described based on a complex of species. Future description of the endogenous development of the parasite in the walls of the intestine of its host may provide new species designations in order to split $L$. occidentalis n. comb.

We provide evidence that lankesterellids are a molecularly diverse group of parasites in lizard hosts, at least in the Americas. Indeed, we found 12 different haplotypes of these parasites in five host lizard species. The absence of Schellackia haplotypes in this sample of New World lizard hosts suggests that the genus Schellackia might be restricted to Old World lizards. Nevertheless, further studies should provide a wider sampling including other localities and host species in North and South America to provide additional evidence on the absence of Schellackia spp. in the Americas. This might have important conservation implications because the eventual introduction of a novel pathogen into America (i.e. Schellackia) through human activity (e.g. pet trade, see [43]) could have a dramatic negative effect on native lizards.

One of the host lizards included in this study, the desert iguana Dipsosaurus dorsalis from Boyd Deep Canyon (CA), was infected by at least four Lankesterella haplotypes (i.e. DD1-DD4). Two possible scenarios may explain the presence of these four clonal parasite haplotypes in a single host individual. On the one hand, these haplotypes could be copies of the same Lankesterella species. Although all known eukaryotes have several clonal copies of the 18S rRNA gene, some apicomplexan species transcribe different copies of this gene along their life-cycle [43]. This is the case for Plasmodium vivax (Apicomplexa: Haemosporidia) [44], and it has also been suggested for the coccidian genus Hepatozoon [45]. In our sample, the absence of multiple peaks in the chromatograms from the uncloned sequences does not rule out the possibility that multiple copies of the $18 \mathrm{~S}$ gene were also present. On the other hand, the phylogenetic position of haplotypes D1 and D4 as the sister clade to groups A and B only partially support this assumption. In this sense, the presence of different haplotypes of the 18S rRNA gene in one individual might reflect the presence of a mixed infection with different parasite species. Indeed, many cryptic species may occur within Apicomplexa $[42,46]$ because hematic stages of unicellular parasites may lack enough diagnostic morphological traits to distinguish easily among species when mixed infections occur [47].

Previous studies on vector-parasite evolution suggest that vector diversity and vector-protozoan specificity may be high in avian models [48]. If that also occurs in lizards, the high genetic diversity of hemococcidians detected in the present study might be related to the high diversity of their vectors, indicating high vector-parasite specificity. A recent publication described high genetic diversity of Lutzomyia (Diptera: Psychodidae) sand flies in California [49]. Measures of genetic differentiation indicated genetic differentiation of this vector between sites that were approximately $0.5-3.8 \mathrm{~km}$ distant. Lutzomyia sand flies, together with some mite species, have been described as natural vectors for several diseases of lizards caused by protozoans including hemococcidia $[4,50,51]$. Thus, the presence of a high genetic diversity of transmitters would favour diversification of host-parasite associations and, hence, diversification of hemococcidian parasites in America.

\section{Conclusions}

Life history traits of hemococcidian parasites such as the type of host blood cells infected, host species or number of refractile bodies are not valid diagnostic characteristics to differentiate the parasites between the genera Schellackia and Lankesterella. Indeed, Lankesterella spp. with a different number of refractile bodies had a close phylogenetic origin. Based on the phylogenetic results we provide a systematic revision of the North American hemococcidians. Our recommendation is to include the species formerly described in the genus Schellackia (i.e. S. golvani and S. occidentalis) that infect American lizards into Lankesterella (Lankesterellidae).

\section{Additional file}

Additional file 1: Table S1. GenBank accession numbers for all sequences included in the phylogenetic analyses. Numbers in column C identify collapsed clades in Fig. 2 (DOCX 24 kb)

\section{Acknowledgements}

We want to thank the staff in the Arboretum at the UCSC for providing us with logistic support and the students who contributed collecting the lizards. We acknowledge the support of the publication fee by the CSIC Open Access Publication Support Initiative through its Unit of Information Resources for Research (URICI).

\section{Funding}

Financial support for molecular analyses was provided by Spanish Ministerio de Economía y Competitividad (projects CGL2012-40026-C02-01 and CGL2015-67789-C2-1-P (MINECO-FEDER) to SM, and CGL2012-40026-C02-02 to JM). RMP was granted to travel and stay in California by the "international short-stay" program EEBB-I-14-08326 as part of the PhD grant BES-2010038427. Research at UCSC was supported by an NSF grant to BS (EF1241848). Financial support in Chile was provided by Fundación Huinay (2013CL0001).

\section{Availability of data and materials}

Voucher blood smears are available at the collection of invertebrates of the Museo Nacional de Ciencias Naturales-CSIC, in Madrid (accession codes: MNCN 35/244-250). All new 185 rDNA Lankesterella sequences are available in GenBank under the accession numbers MF167544-MF167555.

\section{Authors' contributions}

RMP, JM and SM designed the study, JM conducted the experimental work: RMP, MGP, RC, FFY and BS contributed sampling host lizards as part of the project in different parts of the world, RMP, DP, VD and RA, analysed the samples. All authors read and approved the final manuscript. 


\section{Ethics approval}

All permits for capturing the lizards were obtained from the corresponding authorities, and the international protocols for animal welfare were followed. Permits for carrying out this investigation and collecting lizards were provided by the UCSC ethics committee (IACUC), CDFG to RC, IADIZA CONICET MENDOZA and Servicio Agrícola y Ganadero (SAG) in Chile (Resolución exenta: 2056/2013).

\section{Consent for publication}

Not applicable.

\section{Competing interests}

The authors declare that they have no competing interests.

\section{Publisher's Note}

Springer Nature remains neutral with regard to jurisdictional claims in published maps and institutional affiliations.

\section{Author details \\ 'Departamento de Ecología Evolutiva, Museo Nacional de Ciencias Naturales-CSIC, Madrid, Spain. ${ }^{2}$ Departamento de Biomedicina y Biotecnología, Área de Parasitología, Universidad de Alcalá de Henares, Alcalá de Henares, Spain. ${ }^{3}$ Department of Ecology and Evolutionary Biology, University of California, Santa Cruz, California 95064, USA. ${ }^{4}$ Department of Biodiversity, Abasaheb Garware College, Pune, India. ${ }^{5}$ Grupo de Ecofisiología Aplicada al Manejo y Conservación de la Fauna Silvestre, Centro para el Estudio de Sistemas Marinos, Centro Nacional Patagónico, Puerto Madryn, Chubut, Argentina. ${ }^{6}$ Instituto Argentino de Zonas Áridas, Grupo de Investigaciones de la Biodiversidad CONICET MENDOZA, Mendoza, Argentina. ${ }^{7}$ School of Biosciences, The University of Melbourne, Melbourne, VIC, Australia. ${ }^{8}$ Departamento de Biogeografía y Cambio Global, Museo Nacional de Ciencias Naturales-CSIC, Madrid, Spain.}

\section{Received: 13 February 2017 Accepted: 26 September 2017}

\section{Published online: 10 October 2017}

\section{References}

1. Labbé A. Sporozoa. R Berlin Friedländer und Sohn. 1899;

2. Reichenow E. Der Entwicklungsgang der Hämococcidien Karyolysus und Schellackia nov. gen. Sitzungsberichte der Gesellschaft Naturforschender Freunde zu Berlin. 1919;10:440-7.

3. Megía-Palma R, Martínez J, Merino S. Molecular characterization of haemococcidia genus Schellackia (Apicomplexa) reveals the polyphyletic origin of the family Lankesterellidae. Zool Scr. 2014;43:304-12.

4. Telford SRJr. Hemoparasites of the Reptilia. Color Atlas and Text. Boca Raton, FL: CRC Press; 2008. p. 261-73.

5. Desser SS, Siddal ME, Barta JR. Ultrastructural observations on the development stages of Lankesterella minima (Apicomplexa) in experimentally infected Rana catesbeiana tadpoles. J Parasitol. 1990;76:97-103.

6. Landau I. Diversité des mécanismes assurant la pérennité de l'infection chez les sporozoaires coccidiomorphes. Mem Mus Nat Hist Nat (Zool). 1973;77:1-62.

7. Lainson R, de Souza MC, Franco CM. Haematozoan parasites of the lizard Ameiva ameiva (Teiidae) from Amazonian Brazil: a preliminary note. Mem Inst Oswaldo Cruz. 2003;98:1067-70.

8. Upton SJ. Suborder Eimeriorina Léger, 1911. In: Lee JJ, Leedale GF, Bradbury P, editors. The Illustrated Guide to the Protozoa, vol. 1. 2nd ed. Lawrence, KS, USA: Allen Press; 2000. p. 318-39.

9. Bonorris JS, Ball GH. Schellackia occidentalis n. sp., a blood-inhabiting coccidia found in lizards in Southern California. J Protozool. 1955;2:31-4.

10. Rogier $\mathrm{E}$, Landau I. Description de Schellackia golvani n. sp. (Lankesterellidae), parasite de Lézards de Guadeloupe. Bull Mus Natl. Hist Nat. 1975;194:91-7.

11. Lainson R, Shaw JJ, Ward RD. Schellackia landaue sp. nov. (Eimeriorina: Lankesterellidae) in the Brazilian lizard Polychrus marmoratus (Iguanidae): experimental transmission by Culex pipiens fatigans. Parasitology. 1976;72: 225-43.

12. Paperna I, Lainson R. Schellackia (Apicomplexa: Eimeriidae) of the Brazilian tree-frog, Phrynohyas venulosa (Amphibia: Anura) from Amazonian Brazil. Mem Inst Oswaldo Cruz. 1995;90:589-92.
13. Paperna I, Finkelman S. Schellackia ptyodactyli sp. n. of the fan-footed gecko Ptyodactylus hasselquisti from the rift escarpment of the lower Jordan Valley. Folia Parasitol. 1996;43:161-72.

14. Megía-Palma R, Martínez J, Merino S. Phylogenetic analysis based on $18 \mathrm{~S}$ rRNA gene sequences of Schellackia parasites (Apicomplexa: Lankesterellidae) reveals their close relationship to the genus Eimeria. Parasitology. 2013;140: 1149-57.

15. Godfrey SS, Bull M, Murray K, Gardner MG. Transmission mode and distribution of parasites among groups of the social lizard Egernia stokesii. Parasitol Res. 2006;99:223-30.

16. Mansour NS, Mohammed AHH. Lankesterella bufonis sp. nov. parasitizing toads, Bufo regularis Reuss, in Egypt. J Protozool. 1962;9:243-8.

17. Stehbens WE. Observations on Lankesterella hylae. J Protozool. 1966;13:59-62.

18. Lainson R, Paperna I. Light and electron microscope study of a Lankesterella petti n. sp. (Apicomplexa: Lankesterellidae) infecting Bufo marinus (Amphibia: Anura) in Para, North Brazil. Parasite. 1995;2:307-13.

19. Paperna I, Ogara W. Description and ultrastructure of Lankesterella species infecting frogs in Kenya. Parasite. 1996:4:341-9.

20. Merino S, Martínez J, Martínez de la Puente J, Criado-Fornelio Á, Tomás G, Morales J, et al. Molecular characterization of the $18 \mathrm{~S}$ rDNA of an avian Hepatozoon reveals that is closely related to Lankesterella. J Parasitol. 2006;92:1330-5

21. Paperna I, Bastien P, Chavatte J-M, Landau I. Lankesterella poeppigii n. sp. (Apicomplexa, Lankesterellidae) from Bufo poeppigii (Tschudi, 1845) from Peru. Rev Peruana. Biol. 2009;16:165-8.

22. Biedrzycka A, Kloch A, Migalska M, Bielański W. Molecular characterization of putative Hepatozoon sp. from the sedge warbler (Acrocephalus schoenobaenus). Parasitology. 2013;140:695-8.

23. Megía-Palma R, Martínez J, Nasri I, Cuervo JJ, Martín J, Acevedo I, et al. Phylogenetic relationships of Isospora, Lankesterella, and Caryospora species (Apicomplexa: Eimeriidae) infecting lizards. Org Divers Evol. 2016;16:275-88.

24. Telford SR Jr. A species of Schellackia (Apicomplexa: Lankesterellidae) parasitising east and southeast Asian lizards. Syst Parasitol 1993;25:109-117.

25. Finkelman S, Paperna I. Schellackia calotesi n. sp. from agamid lizards of the genus Calotes in Thailand. Parasite. 1998;5:23-6.

26. Bristovetzky M, Paperna I. Life cycle and transmission of Schellackia cf. agamae, a parasite of the starred lizard Agama stellio. Int J Parasitol. 1990;20:883-92.

27. Álvarez-Calvo JA. Nuevas especies de hemococcidios en lacértidos españoles. Cuad Cc. Biol. 1975;4:207-22.

28. Chiriac, E. \& Steopoe, I. (1977) Lankesterella baznosanui nov. sp. parasite endoglobulaire de Lacerta vivipara. Rev Roum Biol. 1977;22:139.

29. Merino S, Potti J. High prevalence of hematozoa in nestlings of a passerine species, the Pied Flycatcher, Ficedula hypoleuca. Auk. 1995;112:1041-3.

30. D'Amico VL, Aguilar R. Phymaturus payuniae blood parasite. Herpetol Rev. 2016:47:301-2.

31. Harris DJ, Maia JPMC, Perera A. Molecular survey of Apicomplexa in Podarcis wall lizards detects Hepatozoon, Sarcocystis, and Eimeria species. J Parasitol. 2012;98:592-7.

32. Talavera G, Castresana J. Improvement of phylogenies after removing divergent and ambiguously aligned blocks from protein sequence alignments. Syst Biol. 2007:56:564-77.

33. Darriba D, Taboada GL, Doallo R, Posada D. jModelTest 2: more models, new heuristics and parallel computing. Nat Methods. 2012;9:772.

34. Huelsenbeck JP, Ronquist F, Nielsen R, Bollback JP. Bayesian inference of phylogeny and its impact on evolutionary biology. Science. 2001;294:2310-4.

35. Ronquist F, Huelsenbeck JPMRBAYES. 3: Bayesian phylogenetic inference under mixed models. Bioinformatics. 2003;19:1572-4.

36. Altekar G, Dwarkadas S, Huelsenbeck JP, Ronquist F. Parallel Metropoliscoupled Markov chain Monte Carlo for Bayesian phylogenetic inference. Bioinformatics. 2004;20:407-15.

37. Guindon S, Dufayard JF, Lefort V, Anisimova M, Hordijk W, Gascuel O. New algorithms and methods to estimate maximum-likelihood phylogenies: assessing the performance of PhyML 3.0. Syst Biol. 2010;59:307-21.

38. Anisimova M, Gil M, Dufayard JF, Dessimoz C, Gascuel O. Survey of branch support methods demonstrates accuracy, power, and robustness of fast likelihood-based approximation schemes. Syst Biol. 2011;60:685-99.

39. ICZN. International Commission. on Zoological Nomenclature: Amendment of articles 8, 9, 10, 21 and 78 of the International Code of Zoological Nomenclature to expand and refine methods of publication. Bull Zool Nomencl. 2012;69:161-9. 
40. Speer CA, Hammond DM. Nuclear divisions and refractile-body changes in sporozoites and schizonts of Eimeria callospermophili in cultured cells. J Parasitol. 1970:461-7.

41. Fayer R. Refractile body changes in sporozoites of poultry coccidia in cell culture. Proc Helm Soc Wash. 2011;36:224-31.

42. Perkins S. Species concepts and malaria parasites: detecting a cryptic species of Plasmodium. Proc Roy Soc London. 2000;267:2345-50.

43. Halla U, Korbel R, Mutschmann F, Rinder M. Blood parasites in reptiles imported to Germany. Parasitol Res. 2014;113:4587-99.

44. Li J, Guttell RR, Damberger SH, Wirtz RA, Kissinger JC, Rogers MJ, et al. Regulation and trafficking of three distinct $18 \mathrm{~S}$ ribosomal RNAs during development of the malaria parasite. J Mol Biol. 1997;269:203-13.

45. Starkey LA, Panciera RJ, Paras K, Allen KE, Reiskind MH, Reichard MV, et al. Genetic diversity of Hepatozoon spp. in coyotes from the south-central United States. J Parasitol. 2013:99:375-8.

46. Bensch S, Pérez-Tris J, Waldenström J, Hellgren O. Linkage between nuclear and mitochondrial DNA sequences in avian malaria parasites: multiple cases of cryptic speciation? Evolution. 2004;58:1617-21.

47. Duszynski DW, Wilber PGA. guideline for the preparation of species descriptions in the Eimeriidae. J Parasitol. 1997;83:333-6.

48. Martínez-de la Puente J, Martínez J, Rivero-de Aguilar J, Herrero J, Merino S. On the specificity of avian blood parasites: revealing specific and generalist relationships between haemosporidians and biting midges. Mol Ecol. 2011;20:3275-87.

49. Neal AT, Ross MS, Schall JJ, Vardo-Zalik AM. Genetic differentiation over a small spatial scale of the sand fly Lutzomyia vexator (Diptera: Psychodidae). Parasit Vectors. 2016;9:550.

50. Klein TA, Young DG, Greiner EC. Telford SRJr, Butler JF. Development and experimental transmission of Schellackia golvani and Schellackia occidentalis by ingestion of infected blood-feeding arthropods. Int J Parasitol. 1988;18:259-67.

51. Schall JJ, Smith TC. Detection of malaria parasite (Plasmodium mexicanum) in ectoparasites (mites and ticks), and possible significance for transmission. J Parasitol. 2006;92:413-5.

\section{Submit your next manuscript to BioMed Central and we will help you at every step:}

- We accept pre-submission inquiries

- Our selector tool helps you to find the most relevant journal

- We provide round the clock customer support

- Convenient online submission

- Thorough peer review

- Inclusion in PubMed and all major indexing services

- Maximum visibility for your research

Submit your manuscript at www.biomedcentral.com/submit 